\title{
Chemoselective reaction of cyanoacetic acid with benzal-4- acetylanilines and fungitoxicity of products
}

\author{
ANJALI SIDHU, J R SHARMA and MANGAT RAI \\ Department of Chemistry, Punjab Agricultural University, Ludhiana 141004 \\ e-mail: anjali_sidhu_pau@yahoo.co.in \\ MS received 29 July 2008; revised 5 December 2008; accepted 19 May 2009
}

\begin{abstract}
Cyanoacetic acid reacted chemoselectively with carbon-nitrogen double bond of benzal-4acetylaniliines, leaving the carbon-oxygen double bond, considered to be more reactive, intact, leading to the formation of mono addition-elimination products rather than bis attack at both the reactive centres, even when the reaction was carried out with two moles of cyanoacetic acid. The product viz. benzalcyanoacetic acid and its derivatives were screened for their fungitoxicity against five pathogenic fungi.
\end{abstract}

Keywords. 4-Aminoacetophenone; cyanoacetic acid; benzal-4-acetylanilines; benzalcyanoacetic acid; fungitoxicity.

\section{Introduction}

Chemistry of multiple bonds has achieved a dramatic development in the past decades ${ }^{1-4}$ because these compounds have been used as substrates in the synthesis of industrial and biological active compounds via ring closure, ${ }^{5-6}$ cycloaddition $^{7-8}$ and condensation reactions. ${ }^{9-11}$ Moreover, the compounds containing carbon-nitrogen, carbon-oxygen and/or carbon-carbon double bond are also known to possess biological activity. ${ }^{4,11-14}$ Reaction of cyanoacetic acid with carbonyl compounds yields condensation products ${ }^{15}$ whereas such a reaction with imines, the compounds containing carbon-nitrogen double bond, results in the formation of various products viz. adducts, ${ }^{16}$ addition-elimination products ${ }^{17}$ coumarinimide derivatives ${ }^{5}$, etc. depending on the starting imine and the reaction conditions. The carbonnitrogen double bond is intermediate ${ }^{18}$ in its reactivity between carbonyl compounds and alkenes. The present work was aimed to study the reaction of cyanoacetic acid with benzal-4-acetylaniline and its C-phenyl derivatives, the compounds containing both carbon-nitrogen double bond as well carbonoxygen double bond and unusual results of this work along with fungitoxicity of the products are being presented in this paper.

\footnotetext{
*For correspondence
}

\section{Experimental}

The melting points were determined on electrical melting point apparatus and are uncorrected. Purity of the compounds was checked by TLC. The compounds gave satisfactory elemental analysis. The IR spectra were recorded on a Perkin Elmer FT-IR spectrometer using $\mathrm{KBr}$ disc. The PMR spectra were recorded on a Brucker Spectrospin $300 \mathrm{MHz}$ spectrometer in $\mathrm{CDCl}_{3}$ with TMS as internal standard. Mass spectra were recorded on Perkin Elmer Clarus 500 Mass Spectrometer.

\subsection{General procedure for the reaction of cyanoacetic acid with benzal-4-acetylanilines}

Benzal-4-acetylaniline/its derivative (1a-10a) (0.01 mol) was taken in dry benzene $(20 \mathrm{ml})$ in a conical flask $(100 \mathrm{ml})$. Then cyanoacetic acid $(0.01 \mathrm{~mol})$ and a few drops of pyridine were added to the above solution. The reaction mixture was heated and shaken briskly for $20 \mathrm{~min}$. The flask was then cooled, stoppered and allowed to stand at room temperature for $24 \mathrm{~h}$. when a crude solid separated out which was filtered and recrystallized from benzene to get pure benzalcyanoacetic acid/its derivative (1b-10b). Evaporation of the solvent from the filtrate yielded gelly like mass, TLC of which indicated the presence of 4-aminoacetophenone and unreacted starting materials. 
Condensation of cyanoacetic acid with benzal-4acetylanilines (1a-10a) in 2:1 molar ratio was also carried out by following the above procedure.

\subsection{In vitro screening for fungitoxicity}

Stock solution of the test compounds and standard fungicides, viz. Indofil M-45 (75\% manganese ethylene bisdithiocarbamate $+2 \%$ Zinc ion), Bavistin 50 WP (methyl-2-benzimidazole carbamate) and Vitavax 75 WP (2,3-dihydro-5-carboxanilido-6methyl-1,4-oxathiin) were prepared by dissolving each chemical $(20 \mathrm{mg})$ in absolute alcohol $(0.5 \mathrm{ml})$ and making up the final volume to $10 \mathrm{ml}$ with sterilized distilled water. Stock solutions of $2000 \mathrm{ppm}$ thus prepared on active ingredient basis were kept in refrigerator till further use to prepare solution of required concentration.

Actively growing ten-day old cultures of the test fungi except $U$. tritici were taken from PDA slants and the spore suspension was made by addition of sterilized distilled water. The suspension was filtered through three layers of sterilized cheese cloth under aseptic conditions in order to remove agar bits and mycelium. Haemocytometer was used to get spore suspension $\left(1 \times 10^{6}\right.$ spore $\left./ \mathrm{ml}\right)$. Screening of the test compounds against $U$. tritici involved floating of fungal spores on the surface of test solution in cavity slides.

Small droplets $(0.02 \mathrm{ml})$ of the test solution and spore suspension in equal amount were seeded in the cavity slides. These slides were kept in petriplates lined with moist filter paper and incubated for $24 \mathrm{~h}$ at $25 \pm 1{ }^{\circ} \mathrm{C}$. The slides were checked for germination and per cent spore germination inhibition was determined from which $\mathrm{ED}_{50}$ values were calculated using Polo Software Program.

\section{Results and discussion}

Condensation of cyanoacetic acid with benzal-4acetylanilines (1a-10a), the compounds synthesized by reaction of 4-aminoacetophenone with benzaldehyde and substituted benzaldehydes (1-10), in equimolar ratio in the presence of pyridine yielded crude solids $(1 b-10 b)$ which were purified by recrystallization from benzene.

\subsection{Spectral analysis}

The IR spectra of the products contained absorption bands at 2225 and $1730 \mathrm{~cm}^{-1}$ depicting the presence of cyano and carboxylic carbonyl group respectively. The absorption at 1590 and $850 \mathrm{~cm}^{-1}$ was due to $-\mathrm{CH}=\mathrm{C}<$ linkage. In addition to the above bands, the absorption bands of functional group of the respective product were also observed. For instance, the absorption band between 3400 and $3300 \mathrm{~cm}^{-1}$ in the compounds $3 \mathrm{~b}, 7 \mathrm{~b}$ and $8 \mathrm{~b}$ was indicative of presence of phenolic group in these products. In the IR spectra of products $9 \mathrm{~b}$ and $10 \mathrm{~b}$, the bands between 1540 and 1500 and $1360-1300 \mathrm{~cm}^{-1}$ were due to nitro group.

In the PMR spectra of the products, the protons resonated in the expected field. Multiplet signals of integration corresponding to six protons in compound $1 \mathrm{~b}$; five protons in the products $2 \mathrm{~b}, 3 \mathrm{~b}, 4 \mathrm{~b}, 9 \mathrm{~b}$ and $10 \mathrm{~b}$; four protons in the compounds $5 \mathrm{~b}, 7 \mathrm{~b}$ and $8 \mathrm{~b}$ and three protons in the product $6 \mathrm{~b}$ observed between $\delta 7.0$ and 7.9 accounted for aromatic protons alongwith one olefinic proton. A singlet at about $\delta$ 4.0 corresponding to three protons in compounds $4 \mathrm{~b}$ and $7 \mathrm{~b}$, six protons in compound $5 \mathrm{~b}$ and nine proton in compound $6 \mathrm{~b}$ indicated the presence of methoxy protons in these products. A one proton singlet at $\delta$ 9.5 in compounds $3 \mathrm{~b}, 7 \mathrm{~b}$ and $8 \mathrm{~b}$ showed the presence of phenolic proton. A two proton quartet at $\delta$ 4.4 and three proton triplet at $\delta 1.5$ in the PMR spectrum of compound $8 \mathrm{~b}$ was due to the protons of ethoxy group. Mass spectra of the products revealed that the molecular ion peak also constituted the base peak.

On the basis of analytical and spectral data, the products have been characterized as benzalcyanoacetic acid and its derivatives. The benzalcyanoacetic acid derivatives alongwith their physical characteristics and molecular ion peaks are recorded in table 1 . Reaction of cyanoacetic acid with $1 \mathrm{a}-10 \mathrm{a}$ in $2: 1$ molar ratio also yielded the same products $1 \mathrm{~b}-10 \mathrm{~b}$ respectively. The formation of benzalcyanoacetic acid and its derivatives can be explained by the attack of the carbanion formed from cyanoacetic acid on carbon-nitrogen double bond of benzal-4-acetylanilines to give unstable addition products which lose 4-aminoacetophenone to yield the stable addition-elimination products (scheme 1).

Cyanoacetic acid thus, reacted chemoselectively with azomethine linkage of benzal-4-acetylanilines (1a-10a) leaving the ketonic moiety, considered to be more reactive, intact under reaction conditions, leading to the formation of mono addition-elimination products rather than bis attack at both the reactive centers, viz. carbon-nitrogen as well as carbon- 
Table 1. Physical characteristics and molecular ion peaks of benzalcyanoacetic acid.

\begin{tabular}{|c|c|c|c|c|c|c|c|c|}
\hline \multirow[b]{2}{*}{ Compound } & \multirow[b]{2}{*}{$\mathrm{R}$} & \multirow{2}{*}{$\begin{array}{c}\text { Melting } \\
\text { point }\left({ }^{\circ} \mathrm{C}\right)\end{array}$} & \multirow{2}{*}{$\begin{array}{l}\text { Yield } \\
(\%)\end{array}$} & \multicolumn{3}{|c|}{ Elemental analysis calculated \% (found) } & \multirow{2}{*}{$\begin{array}{l}\mathrm{M}^{+} \\
(\mathrm{m} / \mathrm{z})\end{array}$} & \multirow{2}{*}{$\begin{array}{l}\text { Molecular } \\
\text { formula }\end{array}$} \\
\hline & & & & C & $\mathrm{H}$ & $\mathrm{N}$ & & \\
\hline $1 b$ & $\mathrm{H}$ & 46 & 88 & $\begin{array}{c}69 \cdot 36 \\
(69 \cdot 40)\end{array}$ & $\begin{array}{c}4 \cdot 05 \\
(4 \cdot 00)\end{array}$ & $\mathrm{C}_{10} \mathrm{H}_{7} \mathrm{NO}_{2}$ & 173 & $\mathrm{C}_{10} \mathrm{H}_{7} \mathrm{NO}_{2}$ \\
\hline $2 b$ & $4-\mathrm{Cl}$ & 105 & 68 & $\begin{array}{c}57.83 \\
(57.90)\end{array}$ & $\begin{array}{c}2 \cdot 89 \\
(2 \cdot 85)\end{array}$ & $\mathrm{C}_{10} \mathrm{H}_{6} \mathrm{NO}_{2} \mathrm{Cl}$ & 207 & $\mathrm{C}_{10} \mathrm{H}_{6} \mathrm{NO}_{2} \mathrm{Cl}$ \\
\hline $3 b$ & $4-\mathrm{OH}$ & 118 & 75 & $\begin{array}{c}63.49 \\
(63.57)\end{array}$ & $\begin{array}{c}3 \cdot 70 \\
(3 \cdot 65)\end{array}$ & $\mathrm{C}_{10} \mathrm{H}_{7} \mathrm{NO}_{3}$ & 189 & $\mathrm{C}_{10} \mathrm{H}_{7} \mathrm{NO}_{3}$ \\
\hline $4 b$ & $4-\mathrm{OCH}_{3}$ & 126 & 67 & $\begin{array}{l}65.02 \\
(64.95)\end{array}$ & $\begin{array}{c}4.43 \\
(4 \cdot 40)\end{array}$ & $\mathrm{C}_{11} \mathrm{H}_{9} \mathrm{NO}_{3}$ & 203 & $\mathrm{C}_{11} \mathrm{H}_{9} \mathrm{NO}_{3}$ \\
\hline $5 b$ & $\begin{array}{l}3-\mathrm{OCH}_{3} \\
4-\mathrm{OCH}_{3}\end{array}$ & 102 & 79 & $\begin{array}{l}61.80 \\
(61.90)\end{array}$ & $\begin{array}{c}4 \cdot 72 \\
(4 \cdot 70)\end{array}$ & $\mathrm{C}_{12} \mathrm{H}_{11} \mathrm{NO}_{4}$ & 233 & $\mathrm{C}_{12} \mathrm{H}_{11} \mathrm{NO}_{4}$ \\
\hline $6 b$ & $\begin{array}{l}3-\mathrm{OCH}_{3} \\
4-\mathrm{OCH}_{3} \\
5-\mathrm{OCH}_{3}\end{array}$ & 108 & 85 & $\begin{array}{c}59 \cdot 32 \\
(59 \cdot 30)\end{array}$ & $\begin{array}{c}4.94 \\
(5 \cdot 00)\end{array}$ & $\mathrm{C}_{13} \mathrm{H}_{13} \mathrm{NO}_{5}$ & 263 & $\mathrm{C}_{13} \mathrm{H}_{13} \mathrm{NO}_{5}$ \\
\hline $7 b$ & $\begin{array}{l}3-\mathrm{OCH}_{3} \\
4-\mathrm{OH}\end{array}$ & 118 & 80 & $\begin{array}{c}60 \cdot 27 \\
(60 \cdot 35)\end{array}$ & $\begin{array}{c}4 \cdot 11 \\
(4 \cdot 10)\end{array}$ & $\mathrm{C}_{11} \mathrm{H}_{9} \mathrm{NO}_{4}$ & 219 & $\mathrm{C}_{11} \mathrm{H}_{9} \mathrm{NO}_{4}$ \\
\hline $8 b$ & $\begin{array}{l}3-\mathrm{OC}_{2} \mathrm{H}_{5} \\
4-\mathrm{OH}\end{array}$ & 68 & 82 & $\begin{array}{l}61.80 \\
(61.85)\end{array}$ & $\begin{array}{c}4 \cdot 72 \\
(4 \cdot 65)\end{array}$ & $\mathrm{C}_{12} \mathrm{H}_{11} \mathrm{NO}_{4}$ & 233 & $\mathrm{C}_{12} \mathrm{H}_{11} \mathrm{NO}_{4}$ \\
\hline $9 b$ & $2-\mathrm{NO}_{2}$ & 58 & 63 & $\begin{array}{c}55.05 \\
(54.95)\end{array}$ & $\begin{array}{l}2.75 \\
(2.70)\end{array}$ & $\mathrm{C}_{10} \mathrm{H}_{6} \mathrm{~N}_{2} \mathrm{O}_{4}$ & 218 & $\mathrm{C}_{10} \mathrm{H}_{6} \mathrm{~N}_{2} \mathrm{O}_{4}$ \\
\hline $10 \mathrm{~b}$ & $3-\mathrm{NO}_{2}$ & 98 & 60 & $\begin{array}{c}55 \cdot 05 \\
(55 \cdot 10)\end{array}$ & $\begin{array}{c}2 \cdot 75 \\
(2 \cdot 70)\end{array}$ & $\mathrm{C}_{10} \mathrm{H}_{6} \mathrm{~N}_{2} \mathrm{O}_{4}$ & 218 & $\mathrm{C}_{10} \mathrm{H}_{6} \mathrm{~N}_{2} \mathrm{O}_{4}$ \\
\hline
\end{tabular}

*The m.p. were determined on electric melting point apparatus and are uncorrected

Table 2. Antifungal potential of benzalcyanoacetic acids.

\begin{tabular}{lccccc}
\hline & \multicolumn{5}{c}{ ED $_{50}$ values $(\mathrm{ppm})$ against } \\
\cline { 2 - 6 } Compound & A. alternata & C. capsici & F. oxysporum & M. roridum & U. tritici \\
\hline $\mathrm{lb}$ & 370 & 120 & 250 & 110 & 170 \\
$2 \mathrm{~b}$ & $*$ & 100 & 240 & 70 & 260 \\
$3 \mathrm{~b}$ & $*$ & 180 & 380 & $*$ & $*$ \\
$4 \mathrm{~b}$ & 170 & 72 & 170 & 150 & $*$ \\
$5 \mathrm{~b}$ & $*$ & 106 & 360 & 640 & 960 \\
$6 \mathrm{~b}$ & 720 & 220 & 760 & 80 & 900 \\
$7 \mathrm{~b}$ & 670 & 740 & $*$ & 350 & 940 \\
$8 \mathrm{~b}$ & 370 & 650 & 740 & $*$ & $*$ \\
$9 \mathrm{~b}$ & $*$ & $*$ & $*$ & $*$ & $*$ \\
$10 \mathrm{~b}$ & $*$ & 960 & $*$ & 252 & $*$ \\
\hline
\end{tabular}

*More than $1000 \mathrm{ppm}$

oxygen double bond even when the reaction was carried out with two moles of cyanoacetic acid.

\subsection{Fungitoxicity of products}

Benzalcyanoacetic acid and its derivatives, $(1 b-10 b)$ were evaluated in vitro for their fungitoxicity against Alternaria alternata, Colletotrichum capsici, Fusarium oxysporum, Myrothecium roridum and
Ustilago tritici by spore germination inhibition method $^{19}$ at various concentrations. The results have been expressed in terms of $\mathrm{ED}_{50}$ values i.e. the effective dose at which 50 per cent spore germination inhibition was caused (table 2). Five of the test compounds possessed $\mathrm{ED}_{50}$ values less than $1000 \mathrm{ppm}$ against $A$. alternata and the most effective among these was found to be 4-methoxybenzalcyanoacetic acid (4b) with $\mathrm{ED}_{50}$ value of $170 \mathrm{ppm}$. All the test compounds except $9 \mathrm{~b}$ had $\mathrm{ED}_{50}$ values less than 
$1000 \mathrm{ppm}$ against $C$. capsici and the most potent among there was 4-methoxybenzalcyanoacetic acid (4b) with $\mathrm{ED}_{50}$ value of $72 \mathrm{ppm}$. Among the seven test compounds which showed $\mathrm{ED}_{50}$ values less than $1000 \mathrm{ppm}$ against $F$. oxysporum, again 4-methoxybenzalcyanoacetic acid (4b) exhibited maximum potential with $\mathrm{ED}_{50}$ value of $170 \mathrm{ppm}$.

The test compounds except $3 \mathrm{~b}, 8 \mathrm{~b}, 9 \mathrm{~b}$, possessed $\mathrm{ED}_{50}$ values less than $1000 \mathrm{ppm}$ against $M$. roridum and the compound namely 4-chlorobenzalcyanoacetic acid (2b) showed the best results with $\mathrm{ED}_{50}$ value of $70 \mathrm{ppm}$. The test compounds were less effective against $U$. tritici and benzalcyanoacetic acid (1b) was the only compound which showed promising activity with $\mathrm{ED}_{50}$ value of $170 \mathrm{ppm}$.

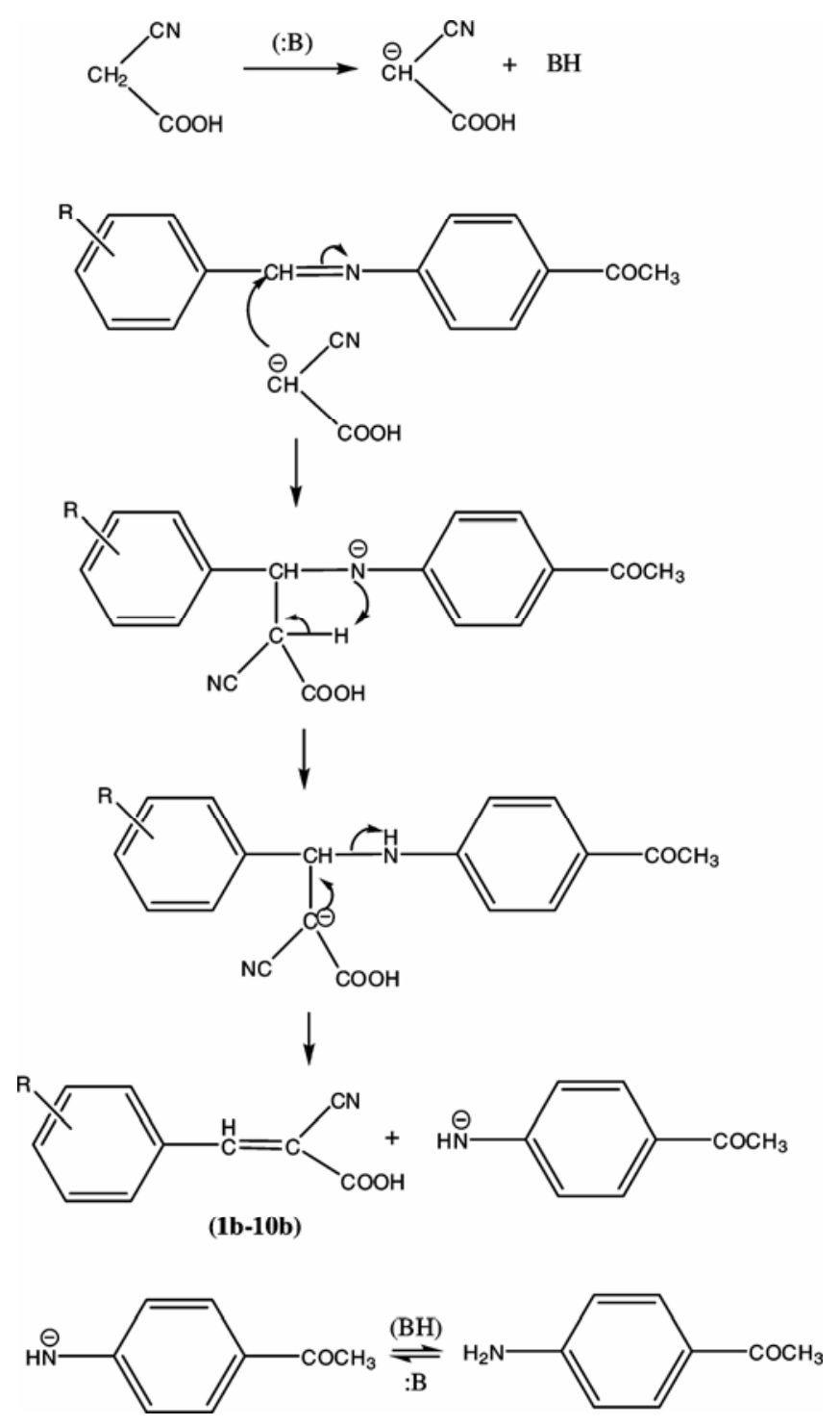

Scheme 1.

\section{Conclusions}

Cyanoacetic acid reacted with carbon-nitrogen double bond of benzal-4-acetylanilines only leaving carbon-oxygen double bond, considered to be more reactive, intact under the reaction conditions. Thus condensation of cyanoacetic acid is a chemoselective reaction with benzal-4-acetylanilines.

4-Methoxybenzalcyanoacetic acid (4b) was found to be most potent among the test compounds against A. alternata, $C$. capsici and $F$. oxysporum with $\mathrm{ED}_{50}$ value of 170,72 and $170 \mathrm{ppm}$, respectively. The most effective compound against $M$. roridum and $U$. tritici was 4-chlorobenzalcyanoacetic acid (2b) and benzalcyanoacetic acid $(1 \mathrm{~b})$ respectively with $\mathrm{ED}_{50}$ value of 70 and $170 \mathrm{ppm}$.

Introduction of nitro-substituent in the phenyl ring of benzalcyanoacetic acid resulted in sharp decline in the fungitoxicity of the parent compound. Thus, the nitro-substituted derivatives $(9 \mathrm{~b}, 10 \mathrm{~b})$ possessed $\mathrm{ED}_{50}$ values of more than $1000 \mathrm{ppm}$ against the test fungi in most of the cases.

\section{Acknowledgements}

The authors are thankful to Council of Scientific and Industrial Research (CSIR), New Delhi for the financial assistance to one of them (AS).

\section{References}

1. Chen G M and Brown H C $2000 \mathrm{~J}$. Am. Chem. Soc. 1224217

2. Hothi H S, Makkar A, Sharma J R and Manrao M R 2006 Eur. J. Med. Chem. 41253

3. Antonov L, Fabian W M F, Nedeltcheia D and Kamounah F S 2000 Perkin II 61173

4. Christopher M V, Liliya G N, David W N, Heather A S, Andreas D, Mark O B, Fleix J B and Stephen A W 2001 Can. J. Chem. 791115

5. Manrao M R, Kohli S, Kalsi P S, Sharma R C and Jhooty J S 1984 Indian J. Chem. 23B 1130

6. Sammour A, Selim M I B and Nour Eldeen $2004 \mathrm{~J}$. Fur. Puatischie. Chemie. 314139

7. Rai M, Kumar S, Krishan K and Singh A 1979 Chem. Ind. 26

8. Rai M and Kaur B 1981 JCS Chem. Comm. 971

9. Sidhu A and Rai M 2008 Indian J. Chem. 47B (in press)

10. Rai M, Kumar S, Krishan K and Singh A 1979 Chem. Ind. 211

11. Thirumalaikumar $M$, Shivasubramanian S, Ponnuswamy A and Mohan P 1996 Eur. J. Med. Chem. 31905 
12. Sandhar R K, Sharma J R and Manrao M R $2008 \mathrm{~J}$. Indian Chem. Soc. 85220

13. Manrao M R, Kaur G and Kaul V K 2007 Indian J. Nem. 37205

14. Sandhar R K, Sharma J R, Kaul V K and Manrao M R 2006 Indian J. Microbiol. 4647

15. Silver R F, Kerr A K, Frandsen P D, Kelley S J and Holmes H L 1967 Can. J. Chem. 45 1001
16. Singh N and Krishan K 1976 Zh. Obshch. Khim. 46 1156

17. Matharu B K, Sharma J R and Manrao M R 2006 Pestic. Res. J. 18113

18. Patai S 1970 The chemistry of the carbon-nitrogen double bond (London: Interscience Publishers) p 105

19. Nene Y L and Thapliyal P N 1993 Fungicides in Plant Disease Control (New Delhi: Oxford and IBH Publishing Co.) p 525 